\title{
Empowerment for Women Laborers Based on "Civic Education" A Case Study of Women Laborers of Cigarette Industry in Malang, Indonesia
}

\author{
Budhy Prianto \\ Department of Public Administrative Science \\ University of Merdeka \\ Malang, Indonesia \\ budhy.prianto@unmer.ac.id
}

\author{
Mardiyono \\ Department of Law \\ University of Merdeka \\ Malang, Indonesia \\ mardiyono@unmer.ac.id
}

\begin{abstract}
Based on our previous research it was known that women workers were in weak position both personally and in the context of industrial relations. The weaknesses were caused by the lack of knowledge and understanding of: rights and obligations as workers, gender, and the rights and obligations as members of society and citizens. The research aimed to increase civic knowledge (cognitive) and understanding (affective) of labor women, especially related to politics. This research uses qualitative experimental approach. The data were mainly obtained from interviews with labor women at post-civic education training. The results of the study show that, first, after training, there were little increase in knowledge and understanding about the politics of labor women. Second, qualitatively the improvement of knowledge and understanding was influenced by the quality of labor women's education and the patriarchy culture shared by the family of labor women.
\end{abstract}

Keywords: empowerment, women, labor, gender, civic education

\section{INTRODUCTION}

That most labor women in cigarette industry, which became participants of research, were the backbone of the family. Though dominant in productive roles, however, the labor women were also had the dominant domestic / reproductive role in the family. In general, they also still appreciate and respect her husband, albeit against a husband who does not have a job [1][2]. However, the de facto patriarchal culture is still deeply embedded in lower class of society, both

among men and women themselves [3][4]. As a result, even though labor women in cigarette industry had strong productive roles, they have not gained public recognition as demanded framework for gender-GFA. Besides women workers remain cigarette industries (required) in the domestic / reproductive role, productive roles, they are not matched by a similar public role.

Based on our previous research [1], it was found that women laborers in the cigarette industry in Malang Municipality were generally in a weak position both personally and in the context of industrial relations. The weakness was caused by the lack of knowledge and understanding about: rights and obligations as labor, gender, and rights and obligations as members of society and citizens. This study aims to improve the knowledge of citizenship and attitude change of women laborers' citizenship, especially with regard to rights and duties as citizens, as laborers, and as women.

\section{RESEARCH METHOD}

This research uses qualitative experimental approach [5]. Data were obtained in two ways, through observation during the training and through personal interviews with participant post civic education training. The trainee were 45 peoples, who divided into three groups, each about 15 peoples based on the location of their residence. Data were focused first on the aspects of the attitude of the trainees during the training, and second on the cognitive and affective aspects of the participants of the materials training. Data about the lack of political knowledge of labor women in cigarette industry had been obtained in our previous research[1]. The data analysis was conducted by descriptive inductive [6] to find the gap, both between the module materials and the

Corresponding authors: Budhy Prianto 
capability of the trainee participantsremembering that women laborers in the cigarette industry were on average only elementary school educated, as well as the possibility of other research focus or variables that were important and not yet summarized in the previous draft module material.

\section{RESULT AND DISCUSSION}

The public role or political role was basically a necessity of the housewives-in this case the workers of the cigarette industry-to actualize themselves in the life of the community in their environment, as well as in the life of the nation and the state. The importance of this public role, according Vermonte [3] was that the public space always provide all kinds of options for women who are active in it to work and rise in rank. In a broader sense this role was more directed to the socializing process of housewives. In general, the roles vary, which were mainly due to the culture and environmental conditions surrounding women, where they had to make steady choices based on their individual capacities. Nevertheless, women often will not be able to play a role in the public and political sectors optimally when they were not supported by their husbands in particular, and men in general [7][1][2][8]. But in principle, if women had the capacity to participate in the public and political sphere, then why are they not given the opportunity [9][10][11].

In the aspect of cognition and affection, the things that will be described were how participants recognize and understand among other things: gender terms and concepts; human rights; politics; political parties; general election; legislative election; democracy; regional head election; and the need for women to engage in politics. Based on the findings of our previous research, the draft of civic education training module had been prepared, with materials consisting of: 1) gender and politics; 2) the Indonesian political system; 3) elections and democracy; 4) political parties and the interests of women laborers.

During the implementation of four-session trainings (materials) the labor women seemed to strive to remain attentive and follow all the training process. Although at first they look excited, but the spirit was getting more and more decreased. Their gestures and behaviors were getting more and more saturated and restless. It could be that the training materials provided were hard for them.
Gender and politics are often regarded as unrelated [12]. Systematically women have been taken away from political affairs, because politics was believed to be man monopoly [13] [9]. Therefore, it's very urgent to give awareness to women laborers about public / political roles through material: Women and women's political rights. The purpose of this material are: 1) Participants understand the meaning of politics; 2) Participants understand and realize the rights and political role of women. In terms of gender, before participating in the training the research participants only heard the term, but in terms of gender it is what they claimed not understand. What Siama says, labor of PT HMS can describe the phenomenon.

"I only ever hear that term once, sir. But that means what I also do not know. If we watch television we watched entertainment only. News events never watched. If watching the news even dizzy".

After training, related with gender to a number of participants were asked questions personally relating to whether they knew and understood the biological differences between men and women, as well as differences in the roles of men and women, and that gender roles were interchangeable. In general, the participants responded that they became more knowledgeable about gender, especially those related to gender roles that could be exchanged. Like the answer of Khusnul, the laborer of PT HMS:

"Although the training was short and solid I became a little more informed and more aware of gender. Although I myself worked and my husband was unemployed, I had previously thought that the role of gender roles was like that, but it turned out to be interchangeable. So in fact, without me knowing I've done".

Similarly, the concept of human rights [9][14]. Prior to the training they claimed to know only the term human rights, but further than that they do not understand. Sometimes among the participants also use the term human rights in conversation with peers, in the family, or among women in the neighborhood. But according to their confession, whether the use of the term human rights they suggested was true or not they also did not know. Answering the question of the researcher, Asmaul, from PT HMS suggested: 
"My knowledge of human rights was only limited to the human rights term, sir. The rest I did not know. Sometimes I and some friends could also joke: you've violated your human rights..... Whether we mean it right or not, we do not know. But, that's what we know about human rights".

After attending the training, labor women generally acknowledged difficulties in capturing training materials. Nevertheless, they claimed their knowledge of human rights has increased, even though their understanding of human rights has shown little improvement. In relation to the political rights of women, labor women also claimed to be more aware that women had political rights. However, they generally assumed that women's political rights had no direct benefit to them, and leave it to others who are more competent to take care of it. Wiwik's statement, female laborers from PR SB at least describe the general opinion.

"Indeed, after training we became a little more informed and more aware of human rights and women's political rights. However, in conditions like us it was difficult for us to use those rights, and let other, more understood and capable people use women's political rights. We want to follow it".

Elections are one of the pillars of democracy [15]. Given the strategic nature of elections, it is appropriate that labor women have sufficient understanding and awareness, so that their involvement in elections really has benefits[16] [17]. Subject matter given in the training: 1) The nature of the general election; 2) Democratic elections and their characteristics; 3) Participation and democratic elections. The aims of this subject are: 1) Participants understand the nature of elections and their aims; 2) Participants understand and recognize the characteristics of democratic elections; 3) Participants understand the role of the society in the implementation of democratic elections. Then it deals with elections.

Prior to participating in the training the labor women as research participants in general also did not understand what the meaning of elections. Nevertheless, they admited that every election and regional head elections (pilkada) -which they know as coblosan (to vote by perforating the ballot)-they always go to polling places to participate in elections. To the researchers Marfuah, PR GL workers say:
"Regarding the election or pilkada I do not understand, sir. Me and some friends at the factory just know that is it coblosan. Every time there is coblosan me and my friends will follow, because if we do not come to worry there is nothing later".

After attending the training, labor women generally claimed to have additional knowledge related to the general election and regional head election. They also become a little more understanding of the meaning of elections and the election of regional heads, both for society in general, and for women workers in particular. The phenomenon can be observed from the Sriatun's statement, women workers of PR SB as follows.

"After participating in the training -related to election materials, although the elucidation of election process is somewhat difficult to capture, we are becoming a little more aware of the meaning of elections, especially for us womanhood. And now more important that we understand why we should come to the polling station to vote at the election".

In terms of how women workers did and made choices, the participants' answers to the researchers are generally similar. In the election, both the presidential election and the legislative elections, and the election of regional heads, to the voters were indeed given the opportunity to elect a political party or to choose an individual person. For the research participants who claimed to be unfamiliar with politics, did not understand the political party and also did not understand what the general election and the election of the head of the region, then the simplest way taken was to just look at the picture of the figure on the voting card. The recognition of Sriatun, a worker in a cigarette company GL could at least represent a description of the attitudes and behaviors of participants in the elections, which states:

"How else, sir... Those parties we did not know and those party peoples we also did not know.... Finally yes just we punch candidates in the picture looks the most beautiful or the most handsome...."

After attending material presentation on how to make choices, both the choice of political parties and the election of figures and the election of regional heads in the electoral process, in general women workers of trainees become more understanding how to make choices. That, as 
women, they should choose political parties or figures that had concern for the women's interests. This kind increase of knowledge and understanding at least in Sriatun, women worker of PR GL, as she said:

"Right sir. By following this training I became more aware that choosing leaders who will represent the interests of the people, especially the womanhood it cannot be just arbitrary. We are required to be able to sort and choose candidate of leaders who care and are willing to fight for the interests of women workers like us".

Political parties and women's interests [18][19]. The main function of political parties is as a bridge that links the interests of the people with the interests of the state [20][21][22]. The interests of women who often have not been voiced should be the starting point of women in choosing the party [23][24][25]. Materials given in the training: 1) Identification of women's interests; 2) Identification of political parties that are friendly to the interests of women. The purpose of the materials are: 1) Participants understand the main function of political parties in voicing women's interests; 2) Participants are able to identify the various interests of women who will be voiced to political parties and that will be used as a reference in choosing political parties.

Furthermore, when questions were directed to participants' knowledge of politics and political parties. Participants also answered not understand. They know the political terms and political parties from the results of hearing the talk of people and briefly heard from television. But the political and political party's understanding was what, they did not know. Associated with the names of political parties, they had only known a few, especially large political parties, which they often see on television or billboards in the streets, such as PKB, Golkar, PDI-P, Nasdem, Democrats, PAN, PKS, PPP , Gerindra, Hanura. The rest they admitted forgot to forget to remember, as told Anik, workers of PR GL to researchers:

"Politics, sir? Wow, I do not understand that. If the names of some political parties I know, because often see on TV or on banners that are often seen scattered in the streets. Also sometimes hear people mention the names of political parties. But yes that's all I know, sir. More than that I do not understand".
A number of women workers after training when asked for responses on political material and political parties generally gave almost the same answer. Generally they claimed that they were still difficult to understand what politics was. However, after training their knowledge of political parties become better. Workers become more aware of the duties and functions of political parties, as well as the duties and functions of political parties in the struggle for women's interests. This was reflected in the responses of Indah, woman workers of PR PM.

"Frankly, sir. We still have trouble understanding what politics is. But for political parties, we are a little bit more understanding. Now we become more aware of what the benefits of political parties are for us, and how we should choose a political party that suits our needs as female workers ".

The results show first, that after training there were little increase knowledge and understanding, as well as changes in views and attitudes about the rights and obligations of women as laborers, as a member of society and as a citizens, and about gender, among labor women in the cigarette industry as participants of the training. Secondly, qualitatively the little increase of knowledge and understanding, as well as the change of views and attitudes toward women's rights and obligations was influenced by the quality of women laborers' education and the culture / values shared by the family of labor women concerned. Third, labor women experience the increase of understanding, change of views and attitudes about patriarchal culture, but because of the still strong patriarchal culture in society around the lives of labor women, they had not had the courage to continue in the realm of action.

\section{CONCLUSION}

The conclusion could be drawn was that, although less encouraging, empowerment through civic education based training for labor women in the cigarette industry in general has been able to increase knowledge (cognitive) and understanding (affective) about citizenship politics, especially related to rights and obligations as citizens, as laborers, and as women. However, due to the still fertile patriarchal culture around the lives of labor women, the increased knowledge and changes in attitudes and views had not been able to be a driver 
of labor women in the form of idea or action to play a role in the public / political domain.

\section{REFERENCES}

[1] B. Prianto and Mardiyono, Woman Workers of Cigarette Industry Among Domestic, Productive, and Public Role (Case Study in Malang Municipality, East Java Province) (Buruh Rokok Perempuan di antara Domestik produktif dan peran public; studi kasus di Malang Jawa Timur), Journal of Culture, Society and Development, Vol. 25, 2016

[2] B.Prianto and A.Utaminingsih. Potrait of Women Apple Garden Workers about "Triple Role" and "Family Decission Making Role" Famale Apple Garden Workers in Poncokusumo- Malang districts (Potret Pekerja Apel Hijau dalam Triple Role dan Peran Pengmabilan Keputusan Keluaga), of Journal Research, Volume XVII, No. 2, 2005

[3] S.F.Vermonte, Denations of Housewives Kompas, September, $3^{\text {rd }}$ in Saturday, 2016

[4] A. Kelbert and N. Hossain, Poor Man's Patriarchy: Gender Roles and Global Crises, IDS Bulletin, 2014, Volume 45 No, 1 January

[5] Sugiyono, Quantitive Research Method (Metode Riset Kuantitatif) dan R \& D, Bandung, Alfabeta Publisher, 2010

[6] J.W.Creswell. "Research Design Qualitative and Quantitative Approach, Mixed Method" (Desain Riset Kualitatif dan Kuantitatif) Third Edition, (translation), Yogyakata, Pustaka Pelajar Publisher, 2010

[7] D. Kandiyoti (1988), Bargaining With Patriarchy, Gender \& Society, 1998, Vol. 2 No. 3, September

[8] Maisah, Household and Human Right, Musãwa, Vol. 15, No. January, $1^{\text {st }} 2016$

[9] Z.F. Arat, Political Parties and Women's Rights in Turkey, British Journal of Middle Eastern Studies, VOL. 44, No. 2, 2017, pp. 240-254

[10] L.J. Benstead, Conceptualizing and Measuring Patriarchy: The Importance of Feminist Theory, in POMEPS Studies 19, Women and Gender in Middle East Politics, May 10, 2016

[11] A. M. Essien and D.P. Ukpong, Patriarchy and Gender Inequality: The Persistence of Religious and Cultural Prejudice in Contemporary Akwa Ibom State, Nigeria, International Journal of Social Science and Humanity, 212, Vol. 2, No. 4, July

[12] R. Glauber and K.L Gozjolko. "Do Traditional Fathers Always Work More? Gender Ideology, Race, and Parenthood", Journal of Marriage and Family Vol. 73, October, 2011, pp. $1133-1148$

[13] M. Tajali. "Protesting gender discrimination from within: women's political representation on behalf of Islamic parties", British Journal of Middle Eastern Studies, 2017, DOI: $10.1080 / 13530194.2017 .1281570$

[14] T. Schofield and S. Goodwin. "Gender Politics and Public Policy Making: Prospects for Advancing Gender Equality", Policy and Society, Volume 24, Issue 4, 2005, $\begin{array}{lrl}\text { pp. } & 25-44, & \text { https://doi.org/10.1016/S1449- } \\ 4035(05) 70067-9 & \end{array}$

[15] M. Budiardjo. The Basics of Political Science (Dasardasar Ilmu Politik), Revised Edition, Jakarta, PT Gramedia Pustaka Utama Publisher. 2008

[16] M.W. Conway. "Women and Political Participation", Political Science and Politics, Vol. 34, No. 2 (Jun., 2001), pp. 231-233

[17] P. Paxton et al, Growth in women's political representation: A longitudinal exploration of democracy, electoral system and gender quotas, European Journal of Political Research 49: 2010, pp.25-52 doi: $10.1111 / \mathrm{j} .1475-6765.2009 .01886 . x$

[18] M. Kenny and T. Verge, Decentralization, Political Parties, and Women's Representation: Evidence from Spain and Britain, Publius:TheJournal of Federalism, 2012, pp.1-20doi:10.1093/publius/pjs023

[19] G.A. Makama. "Patriarcy and Gender Inequality in Nigeria: The Way Forward", European Scientific Journal June, Edition vol.9, No.17, 2013

[20] P. Norris. Political Parties and Democracy in Theoretical and Practical Development In Party Communications, National Democratic Institute for International Affairs (NDI), 2005

[21] R.J.Dalton,Russel J. "Political Parties and Democratic Linkage: How Parties Organized Democracy", Oxford University Press, New York, 2011

[22] J.K. Dubrow, "Do Political Parties Represent Women, the Poor, and the Elderly? Party Images, Party System, and Democracy", International Journal of Sociology, vol. 42 , no. 1, Spring, 2012. pp. 78-86, DOI 10.2753/IJS0020-7659420104

[23] S.Erzeel and K. Celis. "Political parties, ideology and the substantive representation of women", Party Politics, Vol. 22 (5) 2-16,pp.576-586

[24] S. Childs, "In The Absence of Electoral Sex Quotas:Regulating Political Parties for Women's Representation" 49:4, 2013, pp. 401-423, DOI: $10.1080 / 00344893.2013 .850320$

[25] R. Campbell. "Representing women voters: The role of the gender gap and the response of political parties", Party Politics, 2016, pp. 1-11, DOI: $10.1177 / 1354068816655565$ 